\title{
Expression of Vasoactive Intestinal Peptide and Related Receptors in Overcirculation-Induced Pulmonary Hypertension in Piglets
}

\author{
ALINE VUCKOVIC, BENOÎT RONDELET, JEAN-PIERRE BRION, AND ROBERT NAEIJE \\ Laboratory of Physiology and Physiopathology [A.V., B.R., R.N.] and Laboratory of Histology, Neuroanatomy, and Neuropathology \\ [J.-P.B.], Université Libre de Bruxelles, B-1070 Brussels, Belgium
}

\begin{abstract}
The pathobiology of pulmonary arterial hypertension (PAH) is not understood completely. Recent observations in patients with PAH and in knockout models have raised the idea that a defect in vasoactive intestinal peptide (VIP) may be involved in PAH physiopathology. Therefore, we investigated the expressions of VIP, the related pituitary adenylate cyclase-activating polypeptide (PACAP), and their receptors $\left(\mathrm{VPAC}_{1}, \mathrm{VPAC}_{2}\right.$, and $\left.\mathrm{PAC}_{1}\right)$ in piglets with overcirculation-induced pulmonary hypertension as an earlystage PAH model. Seventeen piglets were randomized to an anastomosis between the innominate and the main pulmonary artery, or to a sham operation. After 3 mo, a hemodynamic evaluation was performed and the lung tissue was sampled for biologic and histologic studies. The shunting increased pulmonary vascular resistance (PVR) by $100 \%$ and arteriolar medial thickness by $85 \%$. VIP and $\mathrm{VPAC}_{1}$ gene expressions were decreased and increased, respectively. VPAC $_{1}$ gene expression was positively correlated to PVR. VPAC and $\mathrm{PAC}_{1}$ immunoreactivity was seen in pulmonary arterial smooth muscle. VIP and PACAP immunostaining was observed in nerve fibers surrounding the pulmonary arterial smooth muscle. In conclusion, overcirculation-induced pulmonary hypertension is accompanied by a down-regulation of VIP signaling, without change in PACAP expression. These results are consistent with the notion that abnormal VIP signaling takes part in PAH pathogenesis. (Pediatr Res 66: 395-399, 2009)
\end{abstract}

$\mathrm{T}$ he pathobiology of pulmonary arterial hypertension (PAH) is complex and is not understood completely (1). Several abnormal signaling pathways have been identified, involving the three layers of the pulmonary arterial walls, but their respective roles in initiating or perpetuating the disease remain undefined (1).

Recent observations have drawn attention to a possible implication of the vasoactive intestinal peptide (VIP) and pituitary adenylate cyclase-activating polypeptide (PACAP) systems. VIP belongs to a family of structurally related hormones, including the PACAP. PACAP exists in two forms in mammals ( $\mathrm{PACAP}_{27}$ and $\mathrm{PACAP}_{38}$ ), derived from the same precursor. These ubiquitous and homologous neuropeptides

Received March 17, 2009; accepted May 28, 2009.

Correspondence: Aline Vuckovic, M.D., Laboratory of Physiology and Physiopathology, Université Libre de Bruxelles, Erasmus Campus CP 604, Lennik Road 808, B-1070 Brussels, Belgium; e-mail: avuckovi@ulb.ac.be

This study was supported by grant 3.4515.05 of the "Fonds de la Recherche Scientifique Médicale" (Belgium), the Foundation for Cardiac Surgery (Belgium), the European Commission (Contract no. LHSM-CT-2005-018725, PULMOTENSION), and the "Pôle d'Attraction Interuniversitaire" P6/43 (Belgium). share pleiotropic functions and display highly preserved genes during evolution, suggesting their involvement in important physiologic mechanisms (2). Their actions are mediated through interaction with G-protein-coupled receptors $\left(\mathrm{VPAC}_{1}, \mathrm{VPAC}_{2}\right.$, and $\left.\mathrm{PAC}_{1}\right)$ : $\mathrm{PAC}_{1}$ receptors have greater affinity for PACAP than for VIP, whereas VPAC receptors bind both the peptides with comparable affinity (2). VIP has been reported to promote the relaxation of vascular smooth muscle cells (3); to inhibit the proliferation of pulmonary arterial smooth muscle cells in vitro (4); to reduce pulmonary vasoconstriction induced by endothelin or hypoxia $(5,6)$; and to present with antithrombotic effects (7). The cotransmitter PACAP also demonstrates actions similar to VIP on the pulmonary vasculature, such as vasodilation and inhibition of vascular remodeling (8).

Recent reports have focused on the assessment of the VIP/PACAP system in both patients with PAH and knockout murine models. On one hand, a VIP deficiency together with an overexpression of both VPAC receptors has been reported in a small series of patients with PAH (4). Chronic inhalation of VIP improved hemodynamics and exercise capacity in these patients, introducing the peptide as a possible new treatment for PAH (4). On the other hand, VIP knockout mice developed features of PAH in normoxia, with right ventricular hypertrophy and pulmonary vascular remodeling, both reduced after VIP replacement therapy (9). However, data regarding PACAP and its possible involvement in PAH are scarcer (10).

These findings provide a new aspect of PAH pathobiology that deserves to be explored in early stages of the disease. To our knowledge, VIP, PACAP, and their related receptors have never been explored together in a validated and satisfactory model of PAH. Therefore, we investigated the global VIP/ PACAP system in overcirculation-induced pulmonary hypertension in growing piglets. This experimental model reproduces, in a 3-mo period, significant clinical pulmonary hypertension and small arteriole medial hypertrophy corre-

\footnotetext{
Abbreviations: HR, heart rate; PACAP, pituitary adenylate cyclase-activating polypeptide; PAH, pulmonary arterial hypertension; PAP, mean pulmonary artery pressure; PAPO, occluded PAP; PVR, pulmonary vascular resistance; Q, cardiac output; SAP, systemic arterial pressure; VIP, vasoactive intestinal peptide
} 
sponding to early stages of the disease (11). In the current study, we hypothesized that the VIP/PACAP signaling might be down-regulated in early PAH.

\section{MATERIALS AND METHODS}

Animals and surgical procedure. These experiments were conducted in agreement with the guide for the care and use of laboratory animals of the U.S. National Institutes of Health. Seventeen 3-wk-old piglets were included in this study, with approval by the Committee on the Care and Use of Animals in Research of the Faculty of Medicine of the Free University of Brussels. The left subclavian artery was dissected and anastomosed to the pulmonary arterial trunk, according to the adapted Blalock-Taussig procedure (11). After randomization, the anastomosis was ligated in eight animals (sham-operated controls).

Hemodynamic evaluation and tissue preparation. After a 3-mo observation period, the animals were anesthetized, ventilated, and equipped with catheters and an ultrasonic flow probe on the pulmonary arterial trunk for measurements of mean pulmonary artery pressure (PAP), occluded PAP (PAPO), systemic arterial pressure (SAP), cardiac output (Q), pulmonary arterial flow, heart rate (HR), and blood gases. Pulmonary vascular resistance (PVR) was defined by multipoint (PAP-PAPO)/Q plots obtained by rapid inflation of the inferior vena cava balloon $(11,12)$. Hemodynamic and blood gas measurements were obtained after ensuring steady-state conditions (stable HR, SAP, and PAP) for $60 \mathrm{~min}$ after shunt closure (11). After measurements, the animals were killed with an overdose of anesthesia. Pulmonary tissue samples were immediately frozen in liquid nitrogen and stored at $-80^{\circ} \mathrm{C}$, or after overnight fixation in $10 \%$ formalin, embedded in paraffin for real-time quantitative PCR and histologic procedures, respectively.

Morphometry. Pulmonary arterial morphometry was performed on sections stained immunohistochemically with anti- $\alpha$-smooth muscle actin antibody, as reported previously (11). Only arteries with an external diameter (ED) $<500 \mu \mathrm{m}$ and a complete muscular coat were measured and assigned to five groups according to the ED: 0-75, 76-150, 151-225, 226-300, and $300-500 \mu \mathrm{m}$. Medial thickness (MT) was related to arterial size using the following formula: $\% \mathrm{MT}=(2 \times \mathrm{MT}) /(\mathrm{ED} \times 100)$.

RNA isolation and reverse transcription. Total RNA was extracted from whole lung tissue samples (100 mg), using TRIzol reagent (Invitrogen, http://www.invitrogen.com), according to the manufacturer's protocol. The extracted RNA was quantified by absorbance at $260 \mathrm{~nm}$ (BioPhotometer, Eppendorf, http://www.eppendorf.de), and its concentration was adjusted at $0.25 \mu \mathrm{g} / \mu \mathrm{L}$. Reverse transcription was performed with the GeneAmp PCR system 2400 (Applied Biosystems, http://www.appliedbiosystems.com), using $1 \mu \mathrm{g}$ of total RNA in a total reaction volume of $20 \mu \mathrm{L}$, containing random hexamers, a mix of deoxyribonucleotides, reverse transcription buffer, DTT, ribonuclease inhibitor, and Superscript II reverse transcriptase (Applied Biosystems), according to the manufacturer's instructions. The cDNA synthesis was conducted using the following cycle procedure: $22^{\circ} \mathrm{C}$ for $40 \mathrm{~min}, 42^{\circ} \mathrm{C}$ for $1 \mathrm{~h}$, and $99^{\circ} \mathrm{C}$ for $5 \mathrm{~min}$.

Real-time quantitative PCR. Amplification of reverse-transcribed cDNA sequence for VIP, PACAP, $\mathrm{PAC}_{1}, \mathrm{VPAC}_{1}$, and $\mathrm{VPAC}_{2}$ was obtained by SYBR Green real-time quantitative PCR (Applied Biosystems). The primer sequences (Table 1) were designed on Primer Express software (Applied Biosystems), knowing the already reported porcine sequence for $\mathrm{VPAC}_{1}$ (GenBank NM214036) and the human sequences for VIP (GenBank

Table 1. Primers used for $R T Q-P C R$ for the genes of interest and HPRT gene

\begin{tabular}{|c|c|}
\hline Genes & Primers sequences \\
\hline \multirow[t]{2}{*}{ HPRT } & S: 5'-TCAGGCAGTATAATCAAAGATGGT-3' \\
\hline & AS: 5'-AGTCTGGCTTATATCCAACACTTCG-3' \\
\hline \multirow[t]{2}{*}{ VIP } & S: 5'-CAGCCAACCGTTAGCCATTG-3' \\
\hline & AS: 5'-TGGTGTCCATTTCTGTGCCTC-3' \\
\hline \multirow[t]{2}{*}{ PACAP } & S: 5'-GATGACTCGGAGCCCCTCTC-3' \\
\hline & AS: 5'-CGGCCGCCAAGTATTTCTTA-3' \\
\hline \multirow[t]{2}{*}{$\mathrm{PAC}_{1}$} & S: 5'-TACCTGCACACCCTACTTGCC-3' \\
\hline & AS: 5'-ACCATGATGAAGGTGCTGGG-3' \\
\hline \multirow[t]{2}{*}{$\mathrm{VPAC}_{1}$} & S: 5'-GAGACCCCTGAATCCCCAAA-3' \\
\hline & AS: 5'-GTAGATCCAACCGCCTCACC-3' \\
\hline \multirow[t]{2}{*}{$\mathrm{VPAC}_{2}$} & S: 5'-AAGCCATGTGCCTGGAGAAG-3' \\
\hline & AS: 5'-CCAACACGTGATGTTGTCCC-3' \\
\hline
\end{tabular}

$\mathrm{S}$, sense primer; AS, antisense primer.
NM003381), PACAP (GenBank NM001117), VPAC 2 (GenBank NM003382), and $\mathrm{PAC}_{1}$ (GenBank NM001118). Gene expressions were normalized using hypoxanthine-guanine phosphoribosyltransferase (HPRT) housekeeping gene product as an endogenous reference (11). The primers were produced on an automated synthesizer (Applied Biosystems), according to the manufacturer's protocol (Eurogentec, http://www.eurogentec.com). SYBR Green real-time quantitative PCR analysis was performed with the GeneAmp PCR system 7700 (Applied Biosystems). For each gene, the procedure was realized in duplicate with $25 \mu \mathrm{L}$ reaction volume containing 10 ng of cDNA, $5 \mathrm{pmol} / \mu \mathrm{L}$ of each primer, and $12.5 \mu \mathrm{L}$ of SYBR Green PCR Master Mix (Applied Biosystems). Measurements were made in duplicate. Amplification was conducted as follows: initial denaturation $\left(95^{\circ} \mathrm{C}\right.$ for 10 $\mathrm{min})$, then a two-step cycle program $\left(15 \mathrm{~s}\right.$ at $95^{\circ} \mathrm{C}$ followed by $1 \mathrm{~min}$ at $\left.60^{\circ} \mathrm{C}\right)$ repeated 40 times. To ensure the quality of measurements, we systematically included both negative (no template control) and positive controls in duplicate in each plate. The statistical analysis of PCR results was completed with the comparison between the $C_{\mathrm{t}}$ values of the gene of interest and HPRT $\left(\Delta C_{\mathrm{t}}\right)$. Relative gene expression was obtained by $\Delta \Delta C_{\mathrm{t}}$ methods $\left(\Delta C_{\mathrm{t} \text { sample }}-\Delta C_{\mathrm{t} \text { calibrator }}\right)$, with the sham group as a calibrator, to compare every unknown-sample gene expression levels. The conversion between $\Delta \Delta C_{\mathrm{t}}$ and relative gene expression levels is given by fold induction $=2^{-\Delta \Delta} C_{\mathrm{t}}(12)$.

Immunohistochemistry. The immunohistochemistry analysis was performed using the avidin-biotin complex technique (13). After routine deparaffinization and rehydration, microwave heat pretreatment in citrate buffer was performed before immunolabeling with primary antibodies against VIP, PACAP, and $\mathrm{PAC}_{1}$. Whole lung sections were washed in Tris-buffered saline for $30 \mathrm{~min}$, treated with normal goat serum (1/10 dilution) for $1 \mathrm{~h}$, and incubated overnight at $4^{\circ} \mathrm{C}$ with a commercial primary antibody (rabbit polyclonal IgG; Table 2). After rinsing, the tissue sections were incubated for $30 \mathrm{~min}$ with a goat biotinylated anti-rabbit $\operatorname{IgG}$ at 1/300 dilution (BA-1000, Vector Laboratories, http://www.vectorlabs.com), followed by incubation with the ABC reagent (Vectastain Elite ABC Kit Standard, PK-6100, Vector Laboratories). After $30 \mathrm{~min}$, the slides were rinsed again before developing in 5\% diaminobenzidine tetrahydrochloride chromogenic solution (Dakocytomation, http://www.dako.com). Finally, the specimens were routinely dehydrated, mounted in DPX agent, and coverslipped. Human tissue samples were used as positive controls (liver for VPAC receptors, placenta for PACAP and $\mathrm{PAC}_{1}$, and colon for VIP). Negative controls were generated by omitting the primary antibody.

Data analysis. The values are reported as mean \pm SEM. Tests of statistical significance were performed using the SigmaStat version 3.0 software (Systat Software, http://www.sigmaplot.com). The effects of the shunt on hemodynamic parameters were analyzed by a repeated-measures ANOVA. For relative amounts of mRNA, statistical significance between groups was determined by a one-tailed unpaired $t$ test, after ensuring normality and equality of variance (14). Correlations between PAP, PVR, or MT and mRNA contents were calculated by means of a linear regression analysis. A $p$ value of less than 0.05 was considered as significant.

\section{RESULTS}

Effect of shunting on hemodynamic and morphometric measurements. After a follow-up of 3 mo, the piglets gained $40 \mathrm{~kg}$ weight, with no difference between the two study groups. Blood gases measurements were normal, with no difference between shunted and sham animals. The chronic

Table 2. Primary antibodies used for immunohistochemistry

\begin{tabular}{|c|c|c|}
\hline Commercial primary antibodies & Cross-reaction & Dilution \\
\hline $\begin{array}{l}\text { Anti-VIP (T-4464, Bachem, } \\
\text { https://www.bachem.com) }\end{array}$ & $0 \%$ PACAP & $1 / 500$ \\
\hline $\begin{array}{l}\text { Anti-PACAP }_{38}(\mathrm{~T}-4472, \\
\text { Bachem })\end{array}$ & $0 \% \mathrm{PACAP}_{27}-0 \% \mathrm{VIP}$ & $1 / 500$ \\
\hline $\begin{array}{l}\text { Anti-PACAP }_{27}(\mathrm{~T}-4245, \\
\text { Bachem })\end{array}$ & $\begin{array}{l}1 \% \text { PACAP }_{38}-<0.1 \% \\
\text { VIP }\end{array}$ & $1 / 250$ \\
\hline $\begin{array}{c}\text { Anti-VPAC }{ }_{1} \text { (ab13286, Abcam, } \\
\text { https://www.abcam.com) }\end{array}$ & Not reported & $1 / 100$ \\
\hline $\begin{array}{l}\text { Anti-VPAC } 2(a b 13145, \\
\text { Abcam })\end{array}$ & Not reported & $1 / 100$ \\
\hline Anti-PAC $_{1}$ (ab13374, Abcam) & Not reported & $1 / 100$ \\
\hline
\end{tabular}


left-to-right shunting increased PAP (from $20.1 \pm 1.8$ to $33.2 \pm 1.4 \mathrm{~mm} \mathrm{Hg}, p<0.01$ ), PVR (from $3.7 \pm 0.4$ to $7.5 \pm$ $0.5 \mathrm{~mm} \mathrm{Hg} / \mathrm{L} / \mathrm{min} / \mathrm{m}^{2}, p<0.001$ ), and PAPO (from $7 \pm 1$ to $11 \pm 1 \mathrm{~mm} \mathrm{Hg}, p<0.05$ ), with no change in $\mathrm{Q}$ (from $3.3 \pm$ 0.1 to $3.1 \pm 0.1 \mathrm{~L} / \mathrm{min}$ ), HR (from $112 \pm 8$ to $120 \pm 6$ beats/min), and SAP (from $121 \pm 8$ to $130 \pm 8 \mathrm{~mm} \mathrm{Hg}$ ). Arterial MT of the smallest pulmonary arterioles $(<75 \mu \mathrm{m})$ increased by $85 \%$ in the shunt group in comparison to the sham group (from $13.6 \pm 1.8$ to $25.2 \pm 0.2 \%, p=0.005$; Table 3$)$. The MT was positively correlated to PAP $(p<0.05$; Fig. 1).

Effect of shunting on whole lung $m R N A$ levels. As illustrated in Figure 2, the shunting decreased VIP gene expression (from $1.00 \pm 0.57$ to $0.42 \pm 0.14$ units of relative gene expression; $p=0.05$ ), with an overexpression of $\mathrm{VPAC}_{1}$ (from $1.00 \pm 0.32$ to $3.05 \pm 1.57$ units of relative gene expression; $p<0.05$ ). PAC $_{1}$ expression was also increased by $2.28 \pm 1.68$ times, but this change did not reach statistical significance. There was no modification in mRNA contents for PACAP. No result was available for $\mathrm{VPAC}_{2}$ gene expression because we failed in our attempt to design specific primers able to specifically amplify porcine cDNA. $\mathrm{VPAC}_{1}$ mRNA content was correlated to PVR (Fig. 3), with no correlation to

Table 3. Hemodynamic and morphometric effects of chronic left-to-right shunt in piglets

\begin{tabular}{lcc}
\hline & $\begin{array}{c}\text { Sham } \\
(n=8)\end{array}$ & $\begin{array}{c}\text { Shunt } \\
(n=9)\end{array}$ \\
\hline PAP $(\mathrm{mm} \mathrm{Hg})$ & $20.1 \pm 1.8$ & $33.2 \pm 1.4^{*}$ \\
$\mathrm{PVR}\left(\mathrm{mm} \mathrm{Hg} / \mathrm{L} / \mathrm{min} / \mathrm{m}^{2}\right)$ & $3.7 \pm 0.4$ & $7.5 \pm 0.5^{*}$ \\
$\mathrm{HR}(\mathrm{bpm})$ & $117 \pm 4$ & $121 \pm 6$ \\
$\mathrm{Q}\left(\mathrm{L} / \mathrm{min} / \mathrm{m}^{2}\right)$ & $3.4 \pm 0.1$ & $3.1 \pm 0.1$ \\
$\mathrm{SAP}(\mathrm{mm} \mathrm{Hg})$ & $131 \pm 3$ & $132 \pm 6$ \\
$\mathrm{PAPO}(\mathrm{mm} \mathrm{Hg})$ & $8 \pm 1$ & $10 \pm 1$ \\
$<75 \mu \mathrm{m} \mathrm{pulmonary} \mathrm{artery}$ & $13.6 \pm 1.8$ & $25.2 \pm 1.2 \dagger$ \\
$\quad$ medial thickness $(\%)$ & & \\
\hline
\end{tabular}

Data are expressed as mean \pm SEM.

$* p<0.001$ sham group vs shunt group.

$\dagger p<0.05$ sham group vs shunt group.

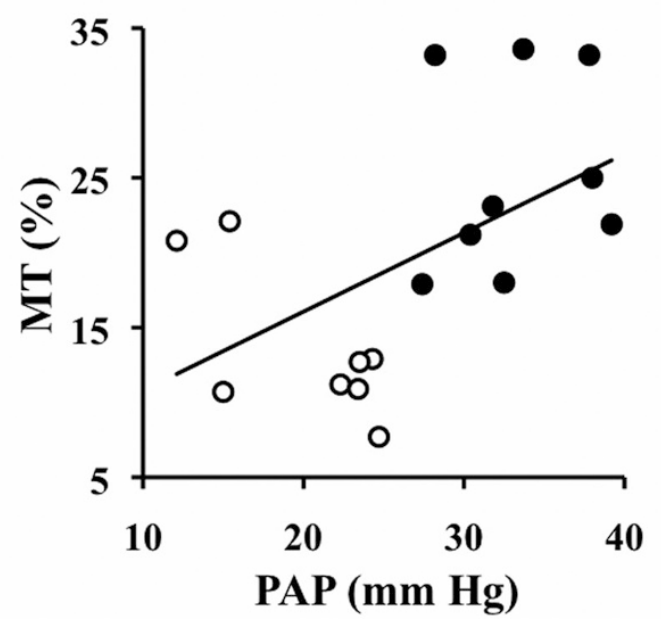

Figure 1. Correlation between mean PAP and the percentage of MT for smallest size pulmonary arterioles (diameter inferior to $75 \mu \mathrm{m}$ ) in shamoperated controls $(\bigcirc)$ and shunted $(\bullet)$ piglets $(r=0.52 ; p<0.05)$.

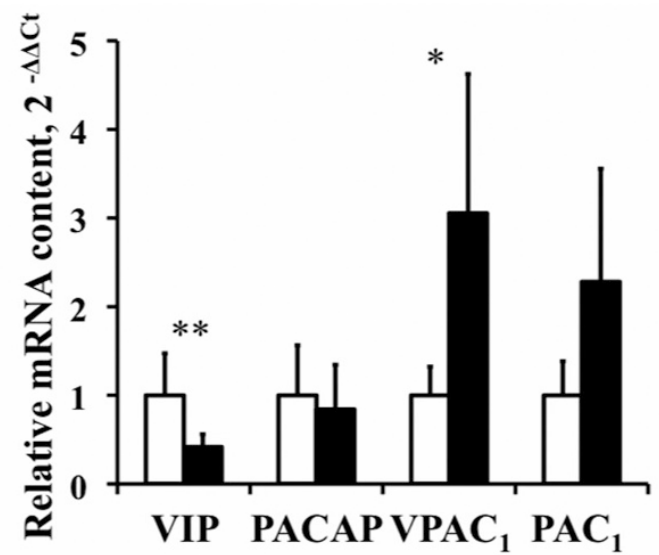

Figure 2. Bar graph showing relative lung tissue mRNA contents for VIP, PACAP, VPAC 1 receptor, and $\mathrm{PAC}_{1}$ receptor of sham-operated $(\square)$ and shunted (ロ) groups. Values are expressed as mean \pm SEM. ${ }^{*} p<0.05$ shunt group $v s$ sham group; $* * p=0.05$ shunt group $v s$ sham group.

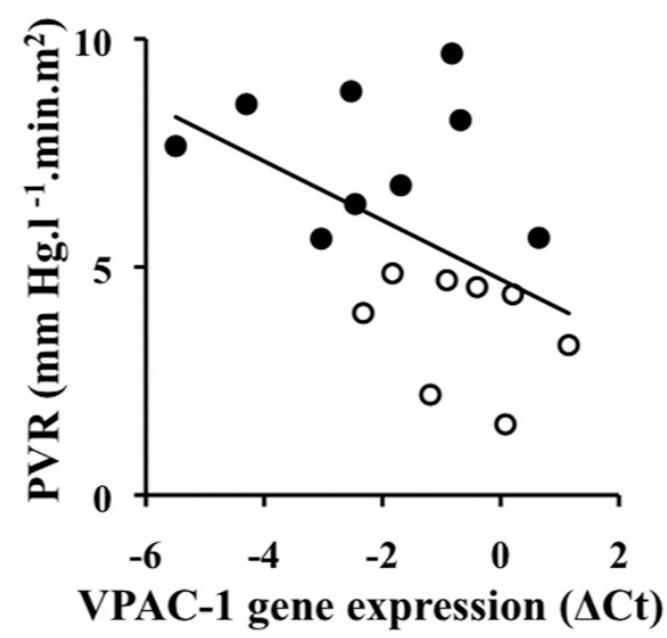

Figure 3. Correlation between relative lung tissue mRNA content for $\mathrm{VPAC}_{1}$ and PVR in sham-operated controls $(\bigcirc)$ and shunted $(\bullet)$ piglets. Values are expressed as mean $\pm \operatorname{SEM}(r=0.48 ; p=0.05)$.

PAP or MT. No other significant correlation was seen between the other gene expressions and hemodynamic or morphometric parameters.

Immunohistochemical localization and distribution of peptides and related receptors in whole lung paraffinembedded sections. The distribution of VIP, PACAP, VPAC ${ }_{2}$, and $\mathrm{PAC}_{1}$ immunoreactivity was similar in both sham and shunt piglets (Fig. 4). VIP and PACAP immunoreactivity was localized in small nerve fibers surrounding the respiratory epithelium and bronchial submucosal glands (data not shown). Immunoreactivity for VIP and PACAP was also observed in nerve fibers around vascular and bronchial smooth muscle cells (panels $A$ and $B$ ). Vascular smooth muscle cells appeared as immunopositive cells for $\mathrm{VPAC}_{2}$ (panel $C$ ). Strong immunoreactivity for $\mathrm{PAC}_{1}$ was shown in arterial smooth muscle cells (panel $D$ ), as well as in chondrocytes, bronchial smooth muscle cells, and respiratory epithelial cells (data not shown). There was no reactivity for $\mathrm{VPAC}_{2}$ and $\mathrm{PAC}_{1}$ in the extracellular matrix. Despite the strong $\mathrm{VPAC}_{1}$ staining shown on positive control specimen (human liver), no immunoreactivity 


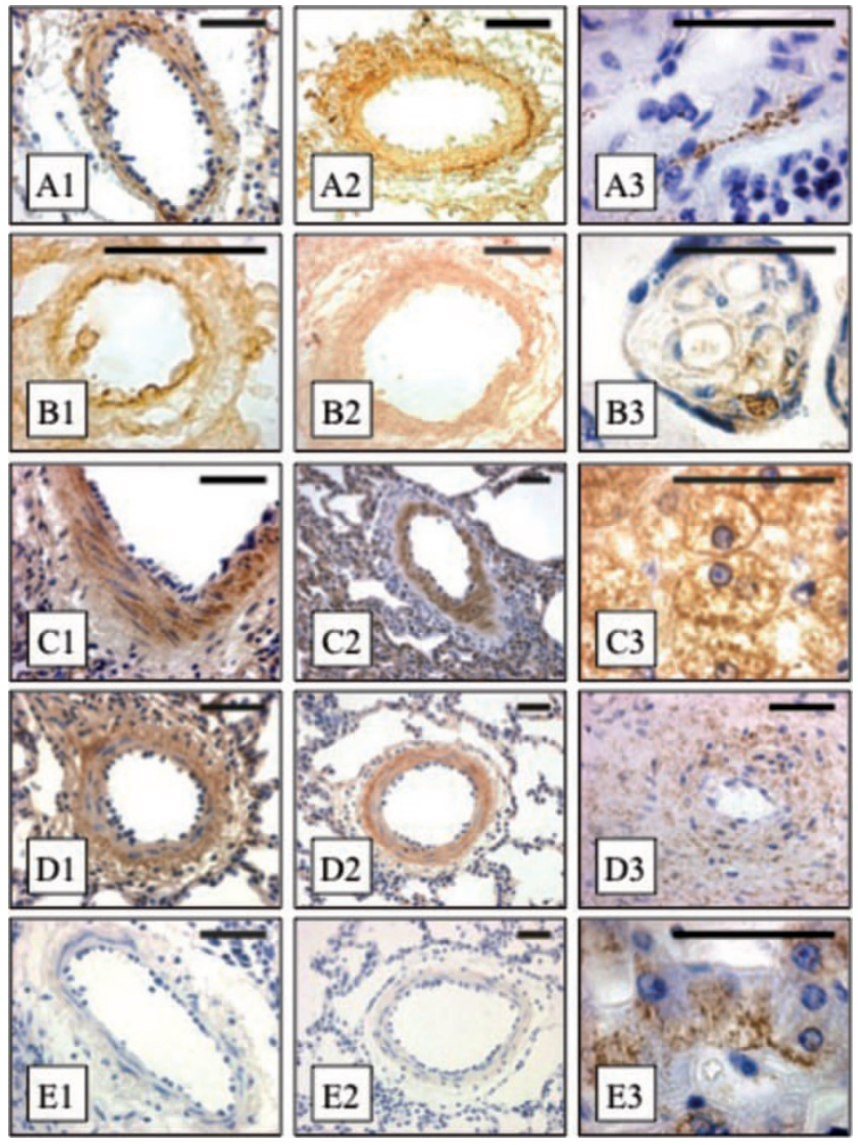

Figure 4. Immunostaining of porcine pulmonary arteries on paraffinembedded sections. Immunoreactivity for VIP (panel A) and for PACAP (panel $B$ ) showing small nerve fibers penetrating pulmonary arterial smooth muscle of sham-operated ( $A 1$, original magnification $\times 40 ; B 1$, magnification $\times 100)$ and shunted piglets ( $A 2$ and $B 2$, magnification $\times 40$ ); VIP immunoreactivity in human colon as a positive control $(A 3$, magnification $\times 100)$; PACAP immunoreactivity in chorionic villi of human placenta as a positive control $(B 3$, magnification $\times 100)$. Immunoreactivity for $\mathrm{VPAC}_{2}$ receptor (panel $C$ ) and for $\mathrm{PAC}_{1}$ receptor (panel $D$ ) showing granular immunoreaction of arterial smooth muscle cells of sham-operated $(C 1$ and $D 1$, magnification $\times 40)$ and shunted piglets $(C 2$ and $D 2$, magnification $\times 20)$; $\mathrm{VPAC}_{2}$ immunostaining in human liver as a positive control $(C 3$, magnification $\times 100)$; $\mathrm{PAC}_{1}$ immunoreactivity in chorionic villi of human placenta as a positive control $(D 3$, magnification $\times 40)$. Negative immunoreaction for $\mathrm{VPAC}_{1}$ receptor in pulmonary tissue of sham-operated $(E 1$, magnification $\times 40)$ and shunted piglets $(E 2$, magnification $\times 20)$; $\mathrm{VPAC}_{1}$ immunostaining in human liver as a positive control $(E 3$, magnification $\times 100)$. Bars $=50 \mu \mathrm{m}$.

could be seen when the porcine lung sections were immunostained for $\mathrm{VPAC}_{1}$ (panel $E$ ). None of the slides used as negative controls showed immunopositive reaction.

\section{DISCUSSION}

Our results demonstrate that growing piglets with overcirculation-induced pulmonary hypertension exhibit a downregulation of VIP together with an up-regulation of $\mathrm{VPAC}_{1}$, without modification of the PACAP axis.

The pathobiology of PAH is characterized by an imbalance of vascular effectors, with vasoconstriction, thrombosis, smooth muscle, and endothelium proliferation. One way to investigate the initial biologic stages of the disease is to develop satisfactory animal models. We previously reported that chronic aorta-pulmonary shunting in growing piglets induces severe pulmonary hypertension, with a PAP between 30 and $40 \mathrm{~mm} \mathrm{Hg}$ at a normal cardiac output measured after shunt closure, and pulmonary arteriolar medial hypertrophy, compatible with reversible PAH related to congenital heart disease with left-to-right shunts. We showed, in this model, an up-regulation of endothelin-1 and phosphodiesterase-5, together with altered angiopoietin-1/BMPR2 signaling $(11,15)$. Pretreatment with phosphodiesterase-5 inhibitor (15), nonselective endothelin-1 receptor antagonist (11), or selective endothelin type A receptor blocker (16) partially prevented the changes in signaling molecules, the increase in PVR, and the thickening of the pulmonary arterial media.

The pulmonary alterations of VIP signaling in this experimental model closely resemble those in patients suffering from severe PAH. In patients with PAH, VIP serum concentrations were decreased, and VIP immunoreactive nerve fibers were nearly absent from the median layer of pulmonary arterial vessels (4). In the left-to-right shunting PAH model, the pulmonary expression of VIP gene was significantly decreased. However, VIP was still detectable by immunostaining in shunted animals and was analogous to that of normal human lung in nerve fibers penetrating arterial and bronchial smooth muscle layers and surrounding the mucous and serous glands (17). Because immunohistology is not sensitive enough for protein quantification, a moderate reduction in nerve fiber VIP protein might have been missed. Furthermore, the implication of VIP in early PAH physiopathology has been emphasized by another experimental model of moderate pulmonary hypertension, namely the VIP knockout model (9). Mice knockout for the VIP gene present with pulmonary hypertension and right ventricular hypertrophy that are reversible by the administration of VIP. In the piglet with shunt-induced $\mathrm{PAH}$, decreased expression of VIP could have been the consequence as well as a contributing factor to increased PVR.

The pivotal role of VIP/PACAP receptors in PAH has been pointed out in patients with severe disease and in animal models. Overexpression of both VPAC receptors at mRNA and protein levels has been reported in pulmonary arterial smooth muscle cells from patients with $\mathrm{PAH}$, in which $\mathrm{VPAC}_{1}$ and $\mathrm{VPAC}_{2}$ were strongly detected by immunohistochemical methods (4). In our porcine model, $\mathrm{VPAC}_{1}$ gene was also up-regulated, which may reflect a response due to the lack of agonist (4). Data regarding $\mathrm{VPAC}_{2}$ gene expression are lacking in this study. Nevertheless, we demonstrated the localization of the correspondent protein in pulmonary arterial smooth muscle cells in accordance with the findings in normal human lung (18). We cautiously refrained to perform semiquantitative estimation only on the basis of $\mathrm{VPAC}_{2}$ immunostaining intensity because the results might not be reproducible with this technique (19). Considering that $\mathrm{VPAC}_{2}$ knockout mice do not develop pulmonary hypertension (20), $\mathrm{VAPC}_{1}$ might be an essential receptor that mediates diseaselimiting actions of VIP in PAH. To date, no transgenic mice have yet been generated with altered gene expression for $\mathrm{VPAC}_{1}$.

The pulmonary gene expression of PACAP and its preferential $\mathrm{PAC}_{1}$ receptor remained unchanged in the current ex- 
periments. $\mathrm{PAC}_{1}$ receptor had a similar distribution to $\mathrm{VPAC}_{2}$ in the porcine pulmonary tissue. $\mathrm{PAC}_{1}$ has not yet been detected by immunohistochemistry in the human lung (18). These results do not favor a role for this pathway in early overcirculation-induced PAH. Our observations contradict previous findings in the $\mathrm{PAC}_{1}$ knockout mice model, in which $\mathrm{PAC}_{1}$ mutants display severe right heart failure and pulmonary arterial muscularization causing death within the first postnatal weeks (10). This might be due to the fact that $\mathrm{PAC}_{1}$ knockout mice developed alveolar hypoxia, leading to secondary pulmonary hypertension. The chronically shunted piglets did not suffer from hypoxia.

Further interactions between VIP signaling and other pathways potentially involved in pulmonary arterial homeostasis will have to be investigated to elucidate the mechanisms by which VIP deficiency takes part in PAH pathophysiology. Apart from a direct effect on vascular smooth muscle cells, VIP vasorelaxant effects may be mediated following an endothelium-dependent manner with activation of endothelial NOS, releasing of NO, and subsequent elevation of cGMP content in arterial smooth muscle cells (21). Endothelin receptors are closely related to vascular endothelium because they participate in NO modulation of endothelin synthesis (22) and release of NO and prostacyclin (23). Taking into account that VIP inhibits the contractile effects of endothelin on pulmonary arteries (5), studies of interactions between endothelin and VIP pathways could take advantage of the existence of endothelin antagonists. Recently, the transforming growth factor- $\beta$ was described as an inducer of VIP gene transcription via the Smad signaling pathway (24). The Smad pathway is involved in angiopoietin-1/BMPR2 signaling, which plays a crucial role in PAH pathogenesis. Overexpression of angiopoietin-1 or mutation of BMPR2 gene down-regulates Smad signaling and enhances proliferative effects on vascular smooth muscle (25). Moreover, VIP deletion in mice is accompanied by an imbalance between vasodilator antiremodeling genes (down-regulation of BMP2, Smad1, endothelial NOS, and prostacyclin synthase) and vasoconstrictor proremodeling ones (up-regulation of angiopoietin 1) (26). Additional knowledge of the relationship between the VIP/ PACAP system and PAH pathobiology could be achieved, thanks to investigations with specific therapies (phosphodiesterase-5 inhibitor or endothelin blockers).

Acknowledgments. We thank Ronald van Beneden for his assistance and Michèle Authelet and Zehra Yilmaz for their excellent technical support in immunohistochemistry.

\section{REFERENCES}

1. Farber HW, Loscalzo J 2004 Pulmonary arterial hypertension. N Engl J Med $351: 1655-1665$
2. Vaudry D, Gonzalez BJ, Basille M, Yon L, Fournier A, Vaudry H 2000 Pituitary adenylate cyclase-activating polypeptide and its receptors: from structure to functions. Pharmacol Rev 52:269-324

3. Henning RJ, Sawmiller DR 2001 Vasoactive intestinal peptide: cardiovascular effects. Cardiovasc Res 49:27-37

4. Petkov V, Mosgoeller W, Ziesche R, Raderer M, Stiebellehner L, Vonbank K, Funk GC, Hamilton G, Novotny C, Burian B, Block LH 2003 Vasoactive intestinal peptide as a new drug for treatment of primary pulmonary hypertension. J Clin Invest 111:1339-1346

5. Janosi T, Peták F, Fontao F, Morel DR, Beghetti M, Habre W 2008 Differential roles of endothelin-1 ETA and ETB receptors and vasoactive intestinal polypeptide in regulation of the airways and the pulmonary vasculature in isolated rat lung. Exp Physiol 93:1210-1219

6. Toubas PL, Sekar KC, Sheldon RE, Pahlavan N, Said SI 1988 Vasoactive intestinal peptide prevents increase in pulmonary artery pressure during hypoxia in newborn lambs. Ann N Y Acad Sci 527:686-687

7. Cox CP, Linden J, Said SI 1984 VIP elevates platelet cyclic AMP (cAMP) levels and inhibits in vitro platelet activation induced by platelet-activating factor (PAF). Peptides 5:325-328

8. Minkes RK, McMahon TJ, Higuera TR, Murphy WA, Coy DH, McNamara DB, Kadowitz PJ 1992 Differential effects of PACAP and VIP on the pulmonary and hindquarters vascular beds of the cat. J Appl Physiol 72:1212-1217

9. Said SI, Hamidi SA, Dickman KG, Szema AM, Lyubsky S, Lin RZ, Jiang YP, Chen JJ, Degene A, Waschek JA, Kort S 2007 Moderate pulmonary arterial hypertension in male mice lacking the vasoactive intestinal peptide gene. Circulation 115:12601268

10. Otto C, Hein L, Brede M, Jahns R, Engelhardt S, Grone HJ, Schutz G 2004 Pulmonary hypertension and right heart failure in pituitary adenylate cyclaseactivating polypeptide type I receptor-deficient mice. Circulation 110:3245-3251

11. Rondelet B, Kerbaul F, Motte S, van Beneden R, Remmelink M, Brimioulle S, McEntee K, Wauthy P, Salmon I, Ketelslegers JM, Naeije R 2003 Bosentan for the prevention of overcirculation-induced pulmonary hypertension. Circulation 107:1329-1335

12. Winer J, Jung CK, Shackel I, Williams PM 1999 Development and validation of real-time quantitative reverse transcriptase-polymerase chain reaction for monitoring gene expression in cardiac myocytes in vitro. Anal Biochem 270:41-49

13. Hsu SM 1990 Immunohistochemistry. Methods Enzymol 184:357-363

14. Motulsky HJ 2002 Biostatistique: Une Approche Intuitive. De Boeck Université Bruxelles, pp 122-124

15. Rondelet B, Kerbaul F, Van Beneden R, Motte S, Fesler P, Hubloue I, Remmelink M, Brimioulle S, Salmon I, Ketelslegers JM, Naeije R 2004 Signaling molecules in overcirculation-induced pulmonary hypertension in piglets: effects of sildenafil therapy. Circulation 110:2220-2225

16. Rondelet B, Kerbaul F, Vivian GF, Hubloue I, Huez S, Fesler P, Remmelink M, Brimioulle S, Salmon I, Naeije R 2007 Sitaxsentan for the prevention of experimental shunt-induced pulmonary hypertension. Pediatr Res 61:284-288

17. Said SI 1988 Vasoactive intestinal peptide in the lung. Ann N Y Acad Sci 527:450-464

18. Busto R, Prieto JC, Bodega G, Zapatero J, Carrero I 2000 Immunohistochemica localization and distribution of VIP/PACAP receptors in human lung. Peptides 21:265-269

19. Taylor CR, Levenson MR 2006 Quantification of immunohistochemistry-issues concerning methods, utility and semiquantitative assessment II. Histopathology 49:411-424

20. Asnicar MA, Köster A, Heiman ML, Tinsley F, Smith DP, Galbreath E, Fox N, Ma YL, Blum WF, Hsiung HM 2002 Vasoactive intestinal polypeptide/pituitary adenylate cyclase-activating peptide receptor 2 deficiency in mice results in growth retardation and increased basal metabolic rate. Endocrinology 143:3994-4006

21. Anaid Shahbazian, Petkov V, Baykuscheva-Gentscheva T, Hoeger H, Painsipp E, Holzer P, Mosgoeller W 2007 Involvement of endothelial NO in the dilator effect of VIP on rat isolated pulmonary artery. Regul Pept 139:102-108

22. Gratton JP, Cournoyer G, Loffler BM, Sirois P, D'Orleans-Juste P 1997 ET(B) receptor and nitric oxide synthase blockade induce BQ-123-sensitive pressor effects in the rabbit. Hypertension 30:1204-1209

23. de Nucci G, Thomas R, D'Orleans-Juste P, Antunes E, Walder C, Warner TD, Vane JR 1988 Pressor effects of circulating endothelin are limited by its removal in the pulmonary circulation and by the release of prostacyclin and endothelium-derived relaxing factor. Proc Natl Acad Sci USA 85:9797-9800

24. Pitts RL, Wang S, Jones EA, Symes AJ 2001 Transforming growth factor-beta and ciliary neurotrophic factor synergistically induce vasoactive intestinal peptide gene expression through the cooperation of Smad, STAT, and AP-1 sites. J Biol Chem 276:19966-19973

25. Du L, Sullivan CC, Chu D, Cho AJ, Kido M, Wolf PL, Yuan JX, Deutsch R, Jamieson SW, Thistlethwaite PA 2003 Signaling molecules in non familial pulmonary hypertension. N Engl J Med 348:500-509

26. Hamidi SA, Prabhakar S, Said SI 2008 Enhancement of pulmonary vascular remodeling and inflammatory genes with VIP gene deletion. Eur Respir J 31:135-139 